\title{
Educational Borrowing and Mathematics Curriculum: Realistic Mathematics Education in the Dutch and Indonesian Primary Curriculum
}

\author{
'Shintia Revina, ${ }^{2}$ Frederick K.S. Leung \\ ${ }^{1}$ Atma Jaya Catholic University of Indonesia, Jl. Jenderal Sudirman 51, Jakarta Pusat, Indonesia \\ ${ }^{2}$ The University of Hong Kong, Pok Fu Lam, Hong Kong \\ e-mail: shintia_revina@yahoo.co.id
}

\begin{abstract}
Abstrak
Sejak akhir 1990-an, para pakar pendidikan matematika Indonesia telah menjadikan Pendidikan Matematika Realistik (RME), pendekatan pendidikan matematika dari Belanda, sebagai dasar reformasi pendidikan. Dalam pembuatan kurikulum Nasional, RME tentunya telah digunakan sebagai salah satu referensi dalam pembuatan tujuan da nisi kurikulum. Dalam kajian ini, sebuah analisa mengenai konsistensi antara RME dan deskripsi serta isi kurikulum di Indonesia disajikan. Kajian ini dilengkapi juga dengan perbandingan mengenai aspek-aspek tersebut dalam kurikulum di Belanda. Temuan penelitian ini menyatakan bahwa meskipun sebagian besar prinsip-prinsip RME terdapat dalam kurikulum matematika sekolah dasar di Indonesia, deskripsinya sangat umum dan kurang eksplisit dibandingkan dengan hal serupa dalam kurikulum di Belanda. Hal ini juga dibatasi oleh pendekatan berdasarkan standard isi dan oleh keberpusatan pengambilan keputusan mengenai konten kurikulum yang diatur pada tingkat nasional. Kajian ini menyarankan studi lanjutan untuk melihat bagaimana kurikulum mempengaruhi bagaimana guru mengimplementasikan RME di kelas.
\end{abstract}

Kata Kunci: Pendidikan Matematika Realistik, kurikulum matematika Sekolah Dasar, kajian kurikulum, educational borrowing

\begin{abstract}
Since the late 1990s, Indonesian mathematics educators have considered Realistic Mathematics Education (RME), the Dutch approach to mathematics instruction, to be the basis for educational reform. In the National curriculum development, RME has, therefore, been reviewed as among the theoretical references to the curriculum goals and content. In the present study, an analysis of the consistency between RME and the curriculum descriptors and contents in Indonesia is presented. This is supplemented with some comparisons to that in the Netherlands. Findings in this study revealed that while most of RME principles are reflected in the Indonesian curriculum, the descriptions were often very general and less explicit compared to the Dutch curriculum. They were also limited by the content-based approach as well as by the centralized decision making process of the contents to be taught which have been pre-determined at the national level. This study suggests future research to see how the curriculum may influence teachers' enactment of RME at classroom level.
\end{abstract}

Keywords: Realistic Mathematics Education, primary mathematics curriculum, curriculum analysis, educational borrowing

How to Cite: Revina, S., \& Leung, F.K.S. (2018). Educational borrowing and mathematics curriculum: Realistic Mathematics Education in Dutch and Indonesian curriculum. International Journal on Emerging Mathematics Education, 2(1), 1-16. http://dx.doi.org/10.12928/ijeme.v2i1.8025

\section{INTRODUCTION}

Owing to its colonial history, Indonesia borrowed its early mathematics curriculum from the Netherlands. Through its development, the Indonesian mathematics curriculum 
has been following the global trends in mathematics education. For example, in the late 1990s, some Indonesian mathematics educators attempted to borrow the Dutch approach to mathematics education, namely the RME, owing to its successful implementation in the Netherlands (Sembiring, Dolk, \& Hadi, 2008). The excellent performance of Dutch students in international assessments such as Trend in Mathematics and Science Study or TIMSS has been attributed to RME (van den Heuvel-Panhuizen \& Wijers, 2005), and so has inspired mathematics educators in many countries, including Indonesia. In Indonesia, RME has been adapted through the Pendidikan Matematika Realistik Indonesia (PMRI) project. In its country of origin, RME has been utilized as a guideline in various areas of mathematics education, including curriculum development (van den Heuvel-Panhuizen \& Wijers, 2005). In Indonesia, RME theory has also been reviewed as among the theoretical references during the 2006 curriculum development (Pusat Kurikulum, 2007). Therefore, it can be anticipated that RME ideas will be reflected in the curriculum documents of both countries. In Indonesia, however, previous research on the consistency between RME and the curriculum remained inconclusive. For instance, some studies reported a consistency between the Indonesian curriculum and RME ideas (Widodo, 2011; Dhoruri, 2010), while a study by Johar, Patahuddin and Widjaja (2017) argued that the structure of the curriculum in Indonesia may contribute to the uniform manner performed by the students in PMRI classroom in solving the given mathematical tasks, which was not desired in an RME lesson. To understand the consistencies between RME and the curricula in Indonesia, this study will firstly discuss the aim and goals of, and the contents covered in, the curriculum. This is followed by a discussion on how they are consistent with the RME principles depicted in van den Heuvel-Panhuizen and Wijers (2005). As a point of reference, some comparisons to the Dutch curriculum were made.

\section{Realistic Mathematics Education}

Gravemeijer (1994) described that the today's Realistic approach is greatly influenced by three prior approaches. Firstly, level theory developed by van Hiele (1973, cited in Gravemeijer, 1994), secondly, Freudenthal's idea of mathematics as human activity, and thirdly progressive mathematization as depicted by Treffers (1987). Van Hiele (1973) distinguishes between three levels of thought in mathematics education: (1) the lower level, associated closely with concrete situations; (2) the second level, which is developing mathematical relationships; and, (3) the third level, whereby a consistency of thought has been achieved and learners are ready for abstract mathematics. Here, learning should begin with concrete situations and learners' tacit informal knowledge, and then gradually allow students to build their own mathematical knowledge that evolves through the learning process. In order to start at the first level - the one that deals with phenomena that are familiar to the learners - Freudenthal argues didactical phenomenology; that learning should start from a meaningful contextual problem. Within the framework of didactical phenomenology, teachers are expected to provide relevant and real-life examples to promote learning (Freudenthal, 1983, 1991). Accordingly, the aim of a phenomenological activity is therefore, "to find problem-situations from which situation specific approaches can be generalized, and to find situations that can evoke paradigmatic solution-procedures as the basis for vertical mathematization" (Gravemeijer \& Terwel, 2000, p.788). In relation to the mathematization process described by Treffers (1987), it can be differentiated into horizontal and vertical mathematization. In the former, learning is shifted from the world of real-life into the world of mathematics, while the latter form emphasizes the process of reorganization

IJEME, Vol. 2, No. 1, March 2018, 1-16. 
within mathematics itself. Although the distinction between the two is useful, in fact they are very closely related to one another. In its operationalization, RME can be characterized by the six principles of RME (van den Heuvel-Panhuizen \& Wijers, 2005). This includes the activity principle, reality principle, level principle, intertwinement principle, interaction principle, and guidance principle. The reality principle discusses about the importance of contextual or real-life problems both as starting point for learning mathematics and for the application of the mathematical concepts learnt. The level principle discusses the needs for using model and schemes to scaffold students' learning. The interactivity principle related to how interaction between teacher and students as well as among students should be conducted. Intertwinement principle suggests the incorporation of different mathematical strands simultaneously. The activity principle stresses that learning should give opportunity for students to be active learners. According to the guidance principle, the teacher must anticipate that their guidance does not conflict with the activity principle.

\section{Borrowing Issues in Education}

In comparative research on education, the term educational borrowing is broadly defined as transplanting, or importing, educational theory or practice that has been developed under a particular context to another context elsewhere (Grant, 2000; Steiner-Khamsi, 2004). The term borrowing itself has often been criticized and alternative descriptors such as adaptation, transfer or assimilation practice have been suggested. In this sense, some research distinguishes between 'borrowed' and 'learned' from others, or between 'adoption' and 'adaptation' practices (De Wet \& Wolhuter, 2007; Dolowitz \& Marsh, 1996; Morris, 2012). For example, Morris (2012, p.90) defined an educational borrowing as "a rational and objective quest to identify and learn from the evidence concerning the universal features of best practices". He argued that comparative educators actually tend to avoid borrowing and, are very cautious towards its implementation. This was based on the assumption that some of the borrowed theory or practice might be too closely bound up with the specific context of its origin, and so may not be effective if transplanted elsewhere. Other studies (Phillips \& Ochs, 2003, p.451) however, suggest that the term 'borrowing' can be used, "to cover the whole range of issues relating to how the foreign example is used by policy makers at all stages of the processes of initiating and implementing educational change". Yet, they often made further distinctions of different degrees or stages of the transfer practice. According to Rose (1991), educational borrowing may have different degrees of mutation between the original and the receiving cultures: from copying, emulation, hybridization, synthesis to inspiration. For example, 'copying' occurs when wholesale features of the foreign theory or practice is adopted, while 'emulating' is when some adaptation is made owing to some contextual factors. 'hybridization', or 'synthesis', occurs when there are efforts to combine the features of the borrowed theory with the current programs in the receiving country, resulting in an original program being created. Finally, 'inspiration' occurs when the efforts result in a fresh program that is expanded and inspired from the original borrowed practice.

In relation to the present study, while one may see the transfer of RME to other contexts as a copying or adoption practice, some scholars may find the term 'adoption' to be inappropriate. For instance, Marpaung, a PMRI expert, argued that the PMRI movement was initiated by a small-scale, bottom-up approach, rather than by a largescale, top-down approach. In practice, while the PMRI teams had adopted most features of the Dutch realistic textbook when developing the local RME-based 
curriculum materials, or when introducing the tenets of RME into teacher development programs, they ensured that they considered Indonesian circumtances, nature and culture (Y. marpaung, personal communication, May 31, 2016). In this sense, it was not a wholesale adoption of RME as some adaptation had been made. In light of the above complexities and debates about the transference of educational practice, this study is sensitive to both adoption and adaption of RME. The present study focuses on identifying the degree of adoption of RME in Indonesia, and the adaptations that have been made by local educators and policy makers. This unified approach was selected to understand the extent to which RME ideas can be accepted and integrated into various aspects of mathematics education in Indonesia, as well as identify those aspects that have changed through the transfer process.

\section{RME-Based Curriculum in Some Countries}

Upon its extensive implementation in the Netherlands, RME has inspired the developments of mathematics education in many countries, including the United States and the United Kingdom. Van den Heuvel-Panhuizen (2010, p.1) stated that RME "was, and still is, in great demand all over the world, even if only perhaps that it gives these countries good hope of being able to attain such high test scores as the Dutch". In the United States, RME was adapted through the project of 'Mathematics in Context' (MiC) in 1991 by the collaboration between the University of Wisconsin-Madison and the Freudenthal Institute (Romberg, 2001; Meyer 1997). Through adaptation, RME ideas were incorporated into a set of curriculum materials developed in collaboration between the American and Dutch educators from the two institutions. The MiC curriculum was one of the curricula aimed at grade five to grade eight in the reformed mathematics education approach launched in the 1990s. The curriculum was considered relevant to the content, teaching, and assessment standards for school mathematics recommended by the NCTM (Meyer, 1997). Accordingly, each unit of the MiC curriculum includes tasks and questions designed to support the vision of NCTM's Professional Standards for Teaching Mathematics.

Inspired by the MiC project, some mathematics educators in Manchester, the United Kingdom, also decided to adapt RME in their curriculum in 2003. Through borrowing, the British educators gained a set of MiC materials developed in the USA. As it received positive responses from British educators, the Manchester Metropolitan University decided to give funding for a pilot project on RME at Key Stage 3, using the US version of Mathematics in Context. In 2007, another project was started, namely, 'Making Sense of Mathematics', which covered the Key Stage 4 of UK schools. This project resulted in ten booklets covering the Key Stage 4 Foundation tier curriculum. These booklets were built upon the experiences gained from the Key Stage 3 project, such as the need for materials from a British context, and an alignment with UK national tests (Dickinson \& Hough, 2012). Nowadays, materials are also being produced for students in higher tiers, with projects following a similar pattern to the former.

In Indonesia, RME has been utilized as one of the theoretical references in the curriculum development. In the policy document, the curriculum official described the five tenets of RME as follows (Pusat Kurikulum, 2007, p.3):

"... in order to improve the low mathematical activity and achievement, nowadays there are some studies conducted on how to teach mathematics in a contextual and humanistic way, as have been implemented earlier in some developed countries. For example, in the Netherlands, there has been developed an educational approach, namely the Realistic Mathematics Education (RME). There are five main characteristics of RME approach: (1)

IJEME, Vol. 2, No. 1, March 2018, 1-16. 
using students' experiences in daily lives (2) visualizing the reality into models, and then shifting the model through vertical mathematization before they reach the formal form, (3) using students' activities, (4) in realizing the mathematics in the students, it is necessary to conduct discussion and question-answer, and (5) there is an intertwining between concepts, or between topics so the mathematics teaching and learning can be more holistic than partial (Ruseffendi, 2003). Utilizing this approach, it is expected that there will be improvement of student outcomes and mathematical activities which can be achieved by delivering materials that is close to the daily lives."

As shown above, the curriculum consults the five tenets of RME (see Gravemeijer, 1994) as the important principles for the teaching and learning of mathematics. This includes the use of students' informal knowledge, the use of models to scaffold learning from informal to formal mathematics, the importance of a student-centered approach, classroom interaction and making connections between various mathematical concepts. However, instead of referring to the original Dutch articles and sources, the curriculum refers to a source by an Indonesian scholar who was among the initiators of the PMRI movement in the country. Although it only mentioned the tenets briefly, it can be seen that the emphasis was on the importance of the use of real-life problems as suggested by the reality principle of RME. Interestingly, in the latter part of the same page, the curriculum also acknowledges the domestic dissemination and development of the Indonesianversion of RME (PMRI), as it says, "Besides, in Indonesia, particularly in the primary grades, an instructional theory, namely 'Pendidikan Matematika Realistik Indonesia' or abbreviated as PMRI, has been disseminated".

\section{RESEARCH METHOD}

In the present study, the exemplary curriculum materials studied include the current Indonesian primary mathematics curriculum document (KTSP) issued by BSNP (Badan Standar Nasional Pendidikan) and the core goals (kerndoelen) of primary mathematics curriculum in the Netherlands issued by the Netherlands Institute for Curriculum Development (SLO). The term curriculum refers to the intended curriculum that is the mathematics that students are expected to learn (Travers \& Westbury, 1989). The analysis of the intended curriculum includes the aims/objectives and the content of curriculum, which is in line with the suggestion by Leung (1992) and Tyler (1949) that discussed the curriculum in terms of aims/objectives, contents, methods and evaluation.

In research on the intended curriculum, document analysis is often chosen as a method. For example, in a study on the mathematics curricula in the Netherlands, van den Heuvel-Panhuizen and Wijers (2005) analyse the Dutch curriculum document and discuss how RME can be reflected in the curriculum description. On the other hand, this document analysis approach is unobtrusive and can provide an objective description of the curriculum documents contents (Berg, 2012; Bowen, 2009). The documentary analysis in this study primarily looked at how RME ideas can be reflected in the curriculum guideline. To analyse the curriculum document, the aims and goals of the curriculum, the curriculum expectation on the mathematical skills and attitudes and the mathematical contents were all examined.

\section{RESULTS AND DISCUSSION}

\section{Aims of the Curriculum}

In relation to the aim of mathematics education at the primary level, both Dutch and Indonesian curricula aim to equip students with a good knowledge of mathematics and its application in contextual situations as well as to develop students' 
way of thinking (intellectual development, creativity, and logical thinking). The curricula also suggests mathematics learning should be joyful for the students. Below is the description of the Dutch primary mathematics curriculum, as depicted in Kerndoelen, or the 'core goals', regarding this aim (SLO, 2004):

"Primary education aims to broadly educate children. The education addresses their emotional and intellectual development, the development of their creativity, and their acquisition of social, cultural and physical skills" (p.1).

"In the course of primary education, the children will gradually acquire - in the context of situations that are meaningful to them - familiarity with numbers, measurements, forms, structures, and the relationships and calculations that apply to these...When selecting and offering the subjects, the children's levels of knowledge and ability are kept in mind, as well as their other areas of development, their interests, and topicalities, so that children will feel challenged to carry out mathematical activity and be able to do maths at their own level, with satisfaction and pleasure" (p.4-5).

While that of the Indonesian is shown below (BSNP, 2006):

"Mathematics is a universal science that underlies the development of modern technology, have an important role in a variety of disciplines and promote the power of human thought... To create and develop the future technology, it is important to have a strong mathematical ability since early ages. Mathematics subject should be taught to all students since the primary years to equip them with the ability to think logically, analytically, systematically, critically and creatively as well as the ability to cooperate. The competencies were important in order for them to acquire the ability to collect, manage, and utilize the information to survive in a keep changing world that is uncertain and competitive... in every opportunity, mathematics learning should be initiated with an introduction of situational problems (contextual problems). By probing a contextual situation, it is expected that students will be gradually guided to master the mathematical concepts" (p. 416-417).

"Curriculum is expected to be implemented by incorporating five principles of learning... Learn to build and find identity through an active, creative and joyful learning process" (p.10).

Despite the similarities, the curricula have different emphases. The Dutch curriculum stresses the importance of a meaningful and personalized mathematics learning style (to learn mathematics at one's own level) and to empower the learners's intelectual ability. The Indonesian currriculum aims to develop students' strong content mastery from an early age to form the foundation of their future mathematical development.

\section{Skills and Attitudes}

In terms of skills, the curricula in the two places are aimed at equiping students with the skills to understand mathematical concepts, as well as developing their communication and problem solving skills.

The Dutch curriculum expectations in terms of skills (SLO, 2004):

- Using Formal Notation of Mathematics

The curriculum expect students to develop their mathematical language in terms of mathematical terms, notations, and schematisation. "This mathematical language 
concerns arithmetical, mathematical and geometrical terms, formal and informal notations, schematic representations, tables and graphs, and exercises for the calculator" (p.4).

- Using of Technical Elements

As shown above, the curriculum also particularly expected students to be able to use a calculator as a tool that can help with technical computation. How and when the calculator is introduced to students, however, is not very clear. Most likely, it may be introduced in the upper grades.

- Mathematical Literacy

The curriculum also specifies that not only do they aim to develop each student's mathematical language, but also his mathematical literacy. The sources of this literacy may come from problems encountered by students in their daily life, in the application of mathematics in other subjects (such as art or physics), or within mathematics itself (e.g. measurement problem). The curriculum states, "they will learn to use 'mathematical language' and gain 'mathematical literacy' and skills in calculus. The subjects according to which children develop their 'mathematical literacy' have different origins: everyday life, other development areas, and mathematics itself' (p.4).

- Communication

The Dutch curriculum emphasizes the needs to develop communication skills in which they aim to develop students' skills in giving an argument and providing a justification (to give and receive criticism). The curriculum states, "they learn to give and receive mathematical criticism with respect for another person's point of view. Explanations, formulations and notations, as well as the giving and receiving of criticism, are all part of a specifically mathematical method that will teach children to organize and motivate ways of thinking and to avoid mistakes, independently as well as together with others" (p.5).

- Problem Solving

The curriculum also expect students to learn problem solving skills in which they are expected to be able to understand a given problem or task and think about how to solve them mathematically. The curriculum states, "they are able to ask mathematical questions and formulate and solve mathematical problems. During the arithmetic or maths lesson, the children learn to solve a problem in a mathematical way and explain to others the solution in mathematical language" (p.5).

The Indonesian curriculum expectations in terms of skills (BSNP, 2006):

- Understand Mathematical Concepts

As aforementioned, the curriculum aims at equiping students with a strong foundation of mathematical knowledge. Therefore, it is important for students "to understand mathematical concepts and see the relationships between them" (p.417).

- Mathematical Reasoning Unlike the Dutch curriculum that uses the term "mathematical literacy", the Indonesian curriculum aims to equip students with the ability to use "mathematical reasoning". Students are expected to be able "to use the reasoning on the patterns and properties, do mathematical manipulation in making generalization, compile evidence, or explain ideas and mathematical statement" (p.417).

- Communication

Similar to that of the Dutch, the Indonesian curriculum also aims to develop students' communication ability. Students are expected to be able to, "communicate ideas using 
symbols, tables, diagrams, or other media to support evidence in problem solving" (p.417). Yet, it does not specify how the communication should be conducted, e.g. whether criticism or argumentation is encouraged.

- Problem Solving In terms of problem solving, the curriculum also aims at develop students problem solving ability. This may include the ability to solve mathematical problems, which includes the ability to understand the mathematical problem, develop a mathematical model, solve the model, and interpret the result. The problems or tasks provided in the classroom, therefore, should be varied. This can be in the form of closed and open questions with a single solution, or open questions with multiple solutions. However, as discussed further in a later section, problem solving was regarded as a different competence to be taught in the curriculum, instead of part of the learning itself (see Table 2).

In terms of attitude, both curricula suggest the importance of building students' motivation and interest, developing their thinking, confidence and cooperative attitudes and the precise aspects of mathematics.

The Dutch curriculum expectation on students' attitude is:

"Explanations, formulations and notations, as well as the giving and receiving of criticism, are all part of a specifically mathematical method that will teach children to organize and motivate ways of thinking and to avoid mistakes, independently as well as together with others" (SLO, 2004, p.5)

The Indonesian curriculum expectation on students' attitude is:

“...to apply the concepts or algorithms flexibly, accurately, efficiently and correctly in problem solving... appreciate the use of mathematics in real life which include developing curiosity, attention and interest in learning mathematics as well as tenacious attitude and confidence in problem solving" (BSNP, 2006, p.417).

\section{Content of the Curriculum}

While the Dutch curriculum comprehensively underlines the importance of how the learning process is expected to be conducted, it only globally describes how the contents should be covered during the six years of primary education. In general, the curriculum covers three domains, namely mathematical insights and operation, numbers and calculation, and measurement and geometry. Below is the curriculum expectation of the mathematical content, for each domain, to be covered in the six years of primary grades (SLO, 2004, p.5):

- Mathematical insight and operation

1. The pupils learn to use mathematical language.

2. The pupils learn to solve practical and formal arithmetical and mathematical problems and clearly represent argumentation.

3. The pupils learn to motivate approaches for solving arithmetical/ mathematical problems and learn to assess solutions.

- Numbers and calculations

1. The pupils learn to understand the general structure and interrelationship of quantities, whole numbers, decimal numbers, percentages, and proportions, and to use these to do arithmetic in practical situations. 
2. The pupils learn to quickly carry out basic calculations in their heads using whole numbers, up to 100 , whereby adding and subtracting up to 20 and the multiplication tables are known by heart.

3. The pupils learn to count and calculate using estimation.

4. The pupils learn clever ways to add, subtract, multiply and divide.

5. The pupils learn to add, subtract, multiply and divide on paper, according to more or less contracted standard procedures.

6. The pupils learn to use the calculator with insight.

- Measuring and geometry

1. The pupils learn to solve simple geometrical problems.

2. The pupils learn to measure and calculate using units and measurements, such as time, money, length, circumference, surface area, volume, weight, speed, and temperature."

As can be seen from the above, the mathematical contents are only briefly described, without specifically mentioning what topic should be taught in which semester, or in what year. Besides, the descriptions of the content, particularly within the mathematical insight and operation domain, attempt to re-emphasize the curriculum expectations on the mathematical skills described in an earlier section. For instance, it mentioned the importance of learning to competently form an argument and to assess a solution. However, as the curriculum does not set what topics should be delivered in what year, the textbooks provide a more detailed guideline of curriculum implementation. For example, according to the textbooks, in grade one, Dutch students will learn the numbers up to 20 , strategies to do operations or calculations using the numbers and the concepts of measurement and geometry that can be incorporated within this topic.

Table 1. Basic competence suggested by Indonesian curriculum (grade 1)

\begin{tabular}{ll}
\hline \multicolumn{1}{c}{$\begin{array}{c}\text { Grade 1 Semester 1 } \\
\text { Competence standards }\end{array}$} & \multicolumn{1}{c}{ Basic Competence } \\
\hline Numbers & 1.1 Counting up to 20 \\
1. Do addition and & 1.2 Ordering the numbers up to 20 \\
subtraction up to 20. & 1.3 Addition and subtraction up to 20 \\
& 1.4 Problem solving of numbers up to 20 \\
Geometry and & 2.1 Defining times, day and hours. \\
Measurement & 2.2 Determining the duration \\
2. Use the measurement of & 2.3 Measuring length of objects through everyday \\
time and length & sentences (short, long) and comparing them \\
& 2.4 Problem solving of measurement of time and \\
3. Learn various three & length \\
dimensional objects & 3.1 Grouping three dimensional objects \\
Grade 1 Semester 2 & Basic Competence \\
Competence standards & \\
Numbers & 4.1 Counting up to 100 \\
4. Do addition and & 4.2 Ordering the numbers up to 100 \\
subtraction of two-digit & 4.3 Place Value: Tens and Ones \\
number (up to 100) in & 4.4 Addition and subtraction up to 100 \\
problem solving & 4.5 Associative and Distributive Law
\end{tabular}




\section{Geometry and \\ Measurement}

5.Use the measurement of weight

6 Learn various shapes
4.6 Problem solving of numbers up to 100

5.1 Comparing weights

5.2 Problem Solving of measurement of weights

6.1 Triangles, Four Sided-Object and circles

6.2 Grouping the shapes

Unlike the Dutch curriculum, which does not apply centralized decisions, the Indonesian curriculum is heavily centralized in terms of mathematical content to be covered. The curriculum rigorously sets all topics that should be introduced during the six years of primary grade education, and in which grades and semester the topics needs to be taught, as presented in Table 1 and 2 .

Table 2. Mathematical content suggested by Indonesian curriculum (grade 1 to 6 )

\begin{tabular}{|c|c|}
\hline $\begin{array}{c}\text { Grade/ } \\
\text { Semester }\end{array}$ & Standard Competence \\
\hline Grade 1/ & Numbers \\
\hline \multirow[t]{5}{*}{ Semester 1} & 1. Do addition and subtraction up to 20 \\
\hline & Geometry and Measurement \\
\hline & 2. Use the measurement of time and length \\
\hline & 3. Learn various three dimensional objects \\
\hline & Numbers \\
\hline \multirow[t]{4}{*}{$\begin{array}{l}\text { Grade 1/ } \\
\text { Semester } 2\end{array}$} & $\begin{array}{l}\text { 4. Do addition and subtraction of two-digit number (up to 100) in } \\
\text { problem solving }\end{array}$ \\
\hline & Geometry and Measurement \\
\hline & 5.Use the measurement of weight \\
\hline & 6 Learn various shapes \\
\hline Grade 2/ & Numbers \\
\hline \multirow[t]{3}{*}{ Semester 1} & 1. Do addition and subtraction up to 500 \\
\hline & Geometry and Measurement \\
\hline & $\begin{array}{l}\text { 2. Use the measurement of time, length and weight in problem } \\
\text { solving }\end{array}$ \\
\hline Grade 2/ & Numbers \\
\hline \multirow[t]{3}{*}{ Semester 2} & $\begin{array}{l}\text { 3. Do multiplication and division of one-digit and two-digit } \\
\text { numbers. }\end{array}$ \\
\hline & Geometry and Measurement \\
\hline & 4. Learn the elements of simple shapes \\
\hline Grade 3/ & Numbers \\
\hline \multirow[t]{2}{*}{ Semester 1} & $\begin{array}{l}\text { 1. Do operation of numbers up to three-digit numbers. } \\
\text { Geometry and Measurement }\end{array}$ \\
\hline & 2. Use measurement of time, length and weight in problem solving. \\
\hline Grade 3/ & Numbers \\
\hline \multirow[t]{4}{*}{ Semester 2} & 3.Learn simple fractions and its application in problem solving \\
\hline & Geometry and Measurement \\
\hline & 4.Understand the elements and properties of various shapes \\
\hline & $\begin{array}{l}\text { 5. Calculate the perimeter and area of square and rectangles and } \\
\text { their application in problem solving }\end{array}$ \\
\hline Grade 4/ & Numbers \\
\hline
\end{tabular}

IJEME, Vol. 2, No. 1, March 2018, 1-16. 
Semester 1 1. Understand and use the properties and rules of the operations of numbers in problem solving

2. Understand and use the factors and multiple in problem solving Geometry and Measurement

3. Use the measurement of angles, length, and weight in problem solving

4. Use the concept of perimeter and area of various shapes in problem solving

Grade 4/ Numbers

Semester 2

5. Add and subtract the whole numbers.

6. Use fractions in problem solving.

7. Use the symbol of Roman numbers.

\section{Geometry and Measurement}

8. Understand the properties of three dimensional space and the relationships between shapes.

\section{Grade 5/ Numbers}

Semester $1 \quad$ 1. Do whole numbers operation in problem solving

Geometry and Measurement

2. Use the measurement of time, angles, distance and speed in problem solving

3. Calculate the area of simple shapes and apply it in problem solving.

Grade 5/

Semester 2

4. Calculate the volume of cubes and cuboids and use it in problem solving

\section{Numbers}

5. Use fractions in problem solving

\section{Geometry and Measurement}

6.Understand the properties of geometrical shapes and their relationship

Grade 6/ Numbers

Semester 1

1. Do operation of whole numbers in problem solving

\section{Geometry and Measurement}

2. Use the measurement of volume (and debit) in problem solving

3. Calculate the area of polygons, circles and the volume of prism

Data Analysis

4. Collect and analyse data

Numbers

Grade 6/ 5. Do operation of fractions in problem solving

Semester $2 \quad$ Geometry and Measurement

6. Use the coordinate system in problem solving

Data Analysis

7. Solve problems that related with data

There are three domains of mathematical content taught to the students in the primary grades: numbers, geometry and measurement, and data analysis. In the Netherlands, data analysis is not explicitly listed in the current curriculum guide, however, according to van den Heuvel-Panhuizen and Wijers (2005), there was an attainment target in the earlier curriculum version (1993/1998), which specified this topic under the measurement strand. As cited in their study (p.294), “... can read simple tables and 
diagrams, and produce them based on own investigations of simple context situations". The distribution of the topics (standard competences) in the Indonesian curriculum for grade one is presented in Table 1, and for all grades in primary years in Table 2 (BSNP, 2006, p.149-158) in which each standard competence is divided into several basic competences. In the Table, it can be seen that the curriculum suggests problem solving to be a different competence to be taught at the end of a topic.The coverage of the contents is compulsory for all schools, within the given time period.

From the above, it can be seen that there are both consistencies and inconsistencies between RME and the Indonesian curriculum descriptions and some notable differences between the RME reflected in the Dutch and Indonesian curriculum. While it is true that most of RME principles are reflected in the Indonesian curriculum, the descriptions were often very general and less explicit compared to the Dutch curriculum. They were also limited by the content-based approach as well as by the centralized decision making process of the contents to be taught which have been pre-determined at the national level. In Indonesian curriculum, it also seems that learning mathematics is learning a set of rules and as the set of rules is small, children should not need much time to master them. This is quite different from the RME vision that children should develop a very broad understanding of numbers and a thorough familiarity with number relations. These findings may also explain the findings of past studies that remained inconclusive. On one hand, the findings in this study confirm previous studies (Widodo, 2011; Dhoruri, 2010) that highlighted the consistency between RME and the Indonesian curriculum, in terms of its emphasis on the importance of using contextual problems and manipulatives, as well as promoting problem solving and active learning. However, the findings in this study also support that of Johar et al. (2017). They argued that the structure of the Indonesian curriculum may lead students to have a single approach to solving mathematical problems. The consistency and inconsistency between Indonesian primary mathematics curriculum and RME are further discussed below, with some comparisons with that of the Dutch.

- Reality Principle

According to the Dutch curriculum, the origin of such situations can be from everyday life, the application of mathematics in other subjects, or in its relation with another mathematical concept. In Indonesia, however, while the importance of initiating a lesson with a contextual problem is stressed, the curriculum suggests problem solving to be taught at the end of each topic, only after students have mastered the necessary concepts. While it is true that RME suggests the contextual problems to be used both as a starting point of learning and as an application of a mathematical concept, in fact, the exploration of mathematics or problem solving is expected to be an integrated part of the learning activities, not as a different competence to be taught (Van den Heuvel-Panhuizen, 2000).

- Level Principle

Both Indonesian and Dutch curricula emphasize the use of models in learning mathematics. These may include concrete objects, manipulatives, models, schematization and tools. In the curricula, students are expected to understand mathematical notation, symbols, tables, diagrams, and use media or tools to support evidence in problem solving, or in developing the mathematical language. However, while the Dutch curriculum is aimed at introducing the use of a calculator, the Indonesian curriculum is not encouraging the introduction of such tools into the primary education. This difference might also influence how mathematics is taught in the two systems. On one side, it is based on the

IJEME, Vol. 2, No. 1, March 2018, 1-16. 
assumption that a calculator can compute the result of a given task, and thus, the importance of learning the mathematical operation is to understand the process and how to interpret the result. On the other hand, one is based on the assumption that the calculation skill is part of the concept mastery, and practice is important. In this view, the use of instruments such as a calculator might interfere with students' understanding of the mathematics.

- Activity and Guidance Principle

In relation to the activity and guidance principle, both curricula suggest mathematics teaching and learning process should actively involve students and teachers should play the important roles of providing appropriate guidance and instructions. As shown in the result section on the aims of the curriculum, in Indonesia, however, the guidance given by teachers is expected to help students to 'gradually master the mathematical concepts', which seems to be placed as the most important goal of the learning process (BSNP, 2006, p. 416-417). On the other hand, the guidance expected by Dutch curriculum is in the form of "taking students interest, ability and topicalities into account when selecting mathematical activities so as students feel challenged and satisfy in learning mathematics at their own level" as the curriculum aims to address the intelectual development of the individual student (SLO, 2004, p. 4-5). This is in line with RME ideas, as Van den Heuvel-Panhuizen and Wijers (2005) pointed out, it is not necessary for all students to learn mathematics at the same level at the same time. In an individualist society such as the Netherlands, it can be understood that an intrinsic motivation is nurtured through meaningful learning. On the other hand, Indonesian curriculum did not explicitly suggest this aspect. This can be understood that in a collectivist society, such personal interests are often limited or de-emphasized.

- Interactivity Principle

In relation to the interactivity principle, the two curricula suggest that students should be helped to develop their communication abilities. The Dutch curriculum, however, explicitly characterized some expectations of how interaction, particularly horizontal interaction, should be conducted. It encourages the training of argumentation and critique, as well as providing justification since early grades as suggested by Yackel and Cobb (1996). In Indonesia, the curriculum also expects teachers to help students to develop their communication abilities, but it does not explicitly advise how such communication skills should be nurtured. The difference, in terms of an explicit expectation of the needs for training to express one's opinion, might be related to how communication is expected to be carried out throughout the larger society. In the Netherlands, and other western countries, training students to express their opinions is often tolerated and regarded positively as standing up for one's beliefs. On the other hand, such training might not be appreciated similarly in Indonesian society which values harmony (Farver, Welles - Nystrom, Frosch, Wimbarti, \& Hoppe-Graff, 1997).

- Intertwinement Principle

In regard to intertwinement principle, the two curricula actually expect students to learn the relationships between mathematical concepts. However, the content-based approach adopted by the Indonesian curriculum may limit the implementation of this principle. The Indonesian system is actually still very conservative towards how mathematics content should be organized in the curriculum. Moreover, there is a rigorous expectation and instruction about how the curriculum should be operationalized in the classroom (see Table 1 and 2). 
In the Netherlands, on the other hand, mathematics and its organization in the curriculum are viewed more flexibly, thus making connections between various mathematical strands possible without having to follow any prescribed order.

The above showed that even when the general descriptions of mathematics curriculum in the Dutch and Indonesian curriculum look quite similar, different emphases were placed. For example, both the Indonesian and Dutch primary mathematics curricula placed high importance on providing opportunities for students to work with contextual problems and developing their problem solving abilities, as suggested by RME. However, the Dutch curriculum put more emphasis on the cognitive and personal development of the learners which aligns with RME, while the Indonesian curriculum emphasized the mastery of mathematical contents more.

Comparing the results with past studies on the adaptation of RME in the curriculum in the United States or in UK, this study found that the extents to which RME has been adopted in Indonesia is quite different from that in those countries. In the American context, the RME-based curriculum was considered relevant to the content, teaching, and assessment standards for school mathematics recommended by the NCTM (Meyer, 1997). It was also evident that there are some characteristics of RME that have been incorporated in the Indonesian curriculum, but many have been changed. Some inconsistencies between the Indonesian curriculum and RME identified in this study may bring conflicts or dilemmas on teachers in trying to implement the reform ideas, or lead them to interpret the ideas superficially. Future study may want to study how the Indonesian curriculum structure and description is influential to the teacher's instructional practice. It is interesting to see how the Indonesian teachers attempt to show compliance towards the curriculum description and contents while addressing the importance of inquiry learning in their RME classrooms.

\section{CONCLUSION}

This study shows that many RME ideas have been changed in its adaptation in Indonesian mathematics curriculum. Given RME has also been transferred to some other countries than Indonesia, the extents to which RME can be adapted in each respective culture is likely to be unique rather than universal. Therefore, it urges to study teachers' intention to enact RME in this context of transfer. This may allow us to understand, for example, how the content-based approach adopted in the national curriculum and the centralized decision making of the contents to be taught influence teachers in enacting the intertwinement principle and the overall RME ideas. Such studies can bring us to an understanding on suggestion from past studies that put expectation on teachers to find a right balance between the borrowed approach and the educational context in their home, which may not be so easily to create. Finally, this study showed that RME was implemented in the Netherlands in line with the various aspects of their mathematics educational and cultural contexts. Consequently, RME is natural for Dutch educators, whereas for Indonesians, the approach is foreign and interpreted through their own contextual lens. This finding suggests that Indonesian educators should be very self-critical when learning from others and when identifying what is best for their local conditions.

\section{REFERENCES}

Berg, B.L. (2012). Qualitative research methods for the social science. Long Beach: Allyn and Bacon. 
Bowen, G.A. (2009). Document analysis as a qualitative research method. Qualitative Research Journal, 9(2), 27-40.

BSNP. (2006). Kurikulum tingkat satuan pendidikan (KTSP). Jakarta: Departemen Pendidikan Nasional.

Cohen, D.K., \& Ball, D.L. (1990). Relations between policy and practice: An overview. Educational Evaluation and Policy Analysis, 12(3), 347-353.

De Wet, C., \& Wolhuter, C. (2007). From 'borrowing' to 'learning' in international comparative study: A critical reflection. South African Journal of Education, 27(2), 317-328.

Dhoruri, A. (2010). Pembelajaran matematika dengan Pendekatan Matematika Realistik (PMR). Yogyakarta: Universitas Negeri Yogyakarta.

Dickinson, P., \& Hough, S. (2012). Using realistic mathematics education in UK classrooms. Manchester: Centre for Mathematics Education, Manchester Metropolitan University.

Dolowitz, D., \& Marsh, D. (1996). Who learns what from whom? A review of the policy transfer literature. Political Studies, 44(2), 343-357.

Farver, J.A.M., Welles-Nystrom, B., Frosch, D.L., Wimbarti, S., \& Hoppe-Graff, S. (1997). Toy stories: Aggression in children's narratives in the United States, Sweden, Germany, and Indonesia. Journal of Cross-Cultural Psychology, 28(4), 393-420.

Freudenthal, H. (1983). Didactical phenomenology of mathematical structures. Dordrecht: Reidel Publishing Company.

Freudenthal, H. (1991). Revisiting mathematics education: China Lectures. Dordrecht: Kluwer Academic Publishers.

Grant, N. (2000). Tasks for comparative education in the new millenium. Comparative Education, 36(3), 309-317.

Gravemeijer, K., \& Terwel, J. (2000). Hans Freudenthal a mathematician on didactics and curriculum theory. Journal of Curriculum Studies, 32(6), 777-796.

Gravemeijer, K. (1994). Developing Realistic Mathematics Education. Utrecht: CD-ß Press/Freudenthal Institute.

Johar, R., Patahuddin, S., \& Widjaja, W. (2017). Linking pre-service teachers' questioning and students' strategies in solving contextual problem: A case study in Indonesia and the Netherlands. The Mathematics Enthusiast, 14(1), 101-128.

Leung, F.K.S. (1992). A Comparison of the intended mathematics curriculum in China,Hong Kong and England and the implementation in Beijing, Hong Kong and London. Ph.D. Thesis. London: University of London.

Meyer, M.R. (1997). Mathematics in context: Opening the gates to mathematics for all at the middle level. NASSP Bulletin, 81(586), 53-59.

Morris, P. (2012). Pick'n'mix, select and project, policy borrowing and the quest for 'world class'schooling: An analysis of the 2010 schools white paper. Journal of Education Policy, 27(1), 89-107.

Phillips, D., \& Ochs, K. (2003). Processes of policy borrowing in education: Some explanatory and analytical devices. Comparative Education, 39(4), 451-461. 
Puskur (Pusat Kurikulum). (2007). Kajian kebijakan kurikulum mata pelajaran matematika [The Study of Mathematics Curriculum Policy]. Jakarta: Badan Penelitian dan Pengembangan Pusat Kurikulum Depdiknas.

Romberg, T.A. (2001). Designing middle-school mathematics materials using problems set in context to help students progress from informal to formal mathematical reasoning. Madison, WI: Wisconsin Center for Education Research.

Rose, R. (1991). What is lesson-drawing? Journal of Public Policy, 11(1), 3-30.

Sembiring, R., Hadi, S., \& Dolk, M. (2008). Reforming mathematics learning in Indonesia classroom through RME. ZDM-The International Journal on Mathematics Education, 40(6), 927-939.

SLO. (2004). Kerndoelen [The Core Goals]. Utrecht: SLO.

Steiner-Khamsi, G. (2004). Globalization in education: Real or imagined? In Gita Steiner-Khamsi, ed., The Global Politics of Educational Borrowing and Lending. New York: Teachers College Press, 1-11.

Taylor, S., Rizvi, F., Lingard, B., \& Henry, M. (1997). Educational policy and the politics of change. London UK: Routledge.

Travers, K.J., \& Westbury, I. (1989). The IEA Studies of Mathematics I: Analysis of Mathematics Curriculum. Oxford: Pergamon.

Treffers, A. (1987). Three dimensions. A Model of goal and theory description in mathematics instruction-the Wiskobas project. Dordrecht: Reidel Publishing Company.

Tyler, R.W. (1949). Basic Principles of Curriculum and Instruction. Chicago: University of Chicago Press.

Van den Heuvel-Panhuizen, M. (2000). Mathematics education in the Netherlands: A guided tour. Freudenthal Institute Cd-rom for ICME9. Utrecht: Utrecht University.

Van den Heuvel-Panhuizen, M. (2010). Reform under attack - Forty years of working on better mathematics education thrown on the Scrapheap? No Way! In L. Sparrow, B. Kissane, and C. Hurst (Eds.), Shaping the future of mathematics education, Proceedings of the 33rd annual conference of the Mathematics Education Research Group of Australasia. Fremantle: MERGA.

Van den Heuvel-Panhuizen, M., \& Wijers, M. (2005). Mathematics standards and curricula in the Netherlands. ZDM, 37(4), 287-307.

Van Hiele, P.M. (1973). Begrip en inzicht: Werkboek van de wiskundedidactiek. Muusses.

Widodo, S. (2011). Teknik-teknik inovasi yang digunakan guru SMP dalam membuat soal matematika kontekstual. Prosiding Seminar Nasional Penelitian, Pendidikan dan Penerapan MIPA. Universitas Negeri Yogyakarta.

Yackel, E., \& Cobb, P. (1996). Sociomathematical norms, argumentation, and autonomy in mathematics. Journal for Research in Mathematics Education, 27(4), 458-477. 